\title{
Tumor Necrosis Factor- $\alpha$-308 G/A Polymorphisms and Risk of Hepatocellular Carcinoma: A Meta-Analysis
}

\author{
Soheil Tavakolpour, ${ }^{1,2}$ and Shahnaz Sali ${ }^{2,}$ \\ ${ }^{1}$ Iran University of Medical Sciences, Tehran, IR Iran \\ ${ }^{2}$ Infectious Diseases and Tropical Medicine Research Center, Shahid Beheshti University of Medical Sciences, Tehran, IR Iran \\ "Corresponding author: Shahnaz Sali, Infectious Diseases and Tropical Medicine Research Center, Shahid Beheshti University of Medical Sciences, Tehran, IR Iran. Tel: \\ +98-9123067784, Fax: +98-2122546026, E-mail: dr.shsali@gmail.com
}

Received 2015 October 02; Accepted 2016 March 14.

\begin{abstract}
Context: Hepatocellular carcinoma (HCC) is a common disorder throughout the world that can develop due to various factors, including genetics. Tumor necrosis factor- $\alpha$ (TNF- $\alpha$ ) is the most frequently studied cytokine related to the risk of developing HCC, and an association between the 308 position of the TNF- $\alpha$ promoter (TNF- $\alpha-308$ ) and HCC risk has been confirmed in various reports. Evidence Acquisition: The PubMed, Scopus, and Google Scholar databases were searched through July 12, 2015, for studies on associations between TNF- $\alpha-308$ and the risk of HCC. To determine this association, odds ratios (ORs) and $95 \%$ confidence intervals (95\% CIs) were calculated.

Results: A total of 23 case-control studies were investigated, involving 3,389 cases and 4,235 controls. The overall conclusion was that the A allele was more frequent in case groups compared to control groups (13.4\% vs. 8.4\%). Thus, the A allele was significantly associated with increased HCC risk $(\mathrm{OR}=1.77 ; 95 \% \mathrm{CI}=[1.26-2.50]$; P value < 0.002). In addition to the allelic model, the dominant model (AA+AG vs. GG) was significantly associated with $\mathrm{HCC}$ risk $(\mathrm{OR}=1.80 ; \mathrm{CI}=[1.29-2.51]$; Pvalue $<0.001)$. In the sensitivity analysis for co-dominant (AA vs. GG) and recessive models (AA vs. AG + GG), no trustworthy associations with the risk of HCC development were observed.

Conclusions: This meta-analysis indicated that the TNF- $\alpha-308$ G/A polymorphism is significantly associated with increased susceptibility to HCC. However, to confirm this finding, more studies are needed on TNF- $\alpha-308$ G/A polymorphisms associated with HCC.
\end{abstract}

Keywords: Tumor Necrosis Factor- $\alpha$, Hepatocellular Carcinoma, Polymorphisms, TNF- $\alpha$-308, Meta-Analysis

\section{Context}

Hepatocellular carcinoma (HCC) is the fifth most common cancer in men and the seventh in women (1), accounting for $70 \%-85 \%$ of primary liver cancers (2). Hepatitis B virus (HBV) and hepatitis $\mathrm{C}$ virus ( $\mathrm{HCV}$ ) infections are the main causes of HCC; however, only a fraction of patients with these infections will develop HCC during their lifetimes. The prevalence of HCC is correlated with the incidence of HBV and HCV in regions with a high risk of these infections, such as Asia and Africa, where HBV and HCV are the primary cause of HCC.

Tumor necrosis factor- $\alpha$ (TNF- $\alpha$ ), which is associated with HCC susceptibility, is a multi-functional cytokine that helps to regulate different pathways involved in inflammation, immunity, apoptosis, anti-apoptosis, and tumorigenesis (3). TNF- $\alpha$ was first believed to be an anti-tumor cytokine, but emerging evidence does not confirm this role. New research has identified TNF- $\alpha$ in a majority of cancers associated with inflammation, acting as a tumorpromoting factor. Indeed, it plays two different roles associated with cancer: it can be an endogenous tumor- promoter, or it can act as a cancer-killer (4) along with activated macrophages, which are the major source of TNF- $\alpha$, monocytes, lymphoid cells, and mast cells. TNF- $\alpha$ can also be produced by various tumor cells, including breast cancer, B-lymphoma, and colon carcinoma. Considerable research has confirmed the role of TNF- $\alpha$ in the promotion and progression of human cancers. It can cause activation of activator protein 1 (AP-1) and nuclear factor-kappa B (NF$\kappa \mathrm{B})$ transcription factors through different pathways (5). In some studies, TNF- $\alpha$ expression was elevated in HCC patients $(6,7)$; however, in other studies, a lower level of TNF$\alpha$ was reported in HCC patients compared to healthy controls $(8,9)$. The critical role of TNF- $\alpha$ in HBV reactivation was also recently discussed by author (10).

Many studies have been performed on the association between the frequency of susceptible TNF- $\alpha$ promoter alleles and HCC development. The most-studied polymorphism of TNF- $\alpha$ promoter positions in HCC development risk are -308 G/A, -238 G/A, -857 C/T, and -863 C/A.

Wilson et al. (11) identified a biallelic polymorphism in the TNF- $\alpha$ promoter at position -308 (TNF- $\alpha-308)$, which 
was introduced as $\mathrm{G}$ to $\mathrm{A}$ transition polymorphism. The $\mathrm{A}$ allele is significantly less common than the $G$ allele globally. It has been suggested that TNF- $\alpha-308$ influences gene expression (12). The A allele in TNF- $\alpha-308$ results in a higher constitutive and inducible level of TNF expression compared to the G allele (13). All of these studies indicate the importance of TNF- $\alpha-308$ polymorphisms in the risk of HCC development.

\section{Evidence Acquisition}

\subsection{Publication Search}

A systematic literature search for all published articles related to HCC and TNF- $\alpha-308$ polymorphisms was conducted using the databases of PubMed, Scopus, and Google Scholar. The last search update was on July 12, 2015, using the keywords "tumor necrosis factor- $\alpha$ " or "tumor necrosis factor-alpha" or "TNF- $\alpha$ ", "polymorphism" or "genotype” or "SNP", and "hepatocellular carcinoma" or "HCC" or "liver cancer". The references for the selected articles were also checked for further related studies.

\subsection{Selection Criteria}

The inclusion criteria were:

1) The study design must be case-control.

2) The outcome should be HCC.

3) The study must include at least two groups, including a case group and a control group.

4) The frequency of alleles and genotypes for both groups, case and control, must be given or calculated.

5) The full article must be published in the English language.

Review articles, systematic reviews, and meta-analyses were excluded, but their references were checked for possible eligible studies based on the above criteria.

\subsection{Data Extraction}

The essential data were extracted from each article by both of the authors independently. All of the extracted data, including year of publication, country, study period, genotyping method, number of cases and controls, and frequency of genotypes and alleles, were categorized, then entered into our database. Any disagreement was discussed until a consensus was reached.

\subsection{Statistical Analysis}

Statistical analyses were carried out using Comprehensive Meta-Analysis (CMA) software, version 2. Odds ratios (ORs) and 95\% confidence intervals (CIs) were used to measure the association between TNF- $\alpha$-308 polymorphisms and the risk of HCC development. A P $<0.05$ was considered statistically significant. Heterogeneity among the studies was examined with the Cochran Q test and $\mathrm{I}^{2}$ statistics. When significant heterogeneity was observed (pheterogeneity $<0.1$ and $\mathrm{I}^{2}>50 \%$ ), the random effect model was used. However, in homogeneous conditions (pheterogeneity $>0.1$ and $\mathrm{I}^{2}<50 \%$ ), the fixed-effect model was employed. Publication bias was investigated visually with funnel plots. For calculation of overall effect size in the absence of one study, a sensitivity analysis was conducted. In this meta-analysis, both the allelic and the genotype genetics models, including per-allele (A vs. G), codominant (AA vs. GG), dominant (AA + AG vs. GG), and recessive models (AA vs. AG $+\mathrm{GG}$ ), were analyzed in order to evaluate the associations between the TNF- $\alpha-308 \mathrm{G} / \mathrm{A}$ allele and HCC development risk.

\section{Results}

\subsection{Publication Search}

A total of 287 articles were identified in the database search. Only articles in the English language were chosen for primary screening. After omitting 53 duplicate studies, 234 articles were considered for skimming of titles and abstracts, and 52 articles were subsequently selected for careful scanning of the context. More than half of these (29 studies) were excluded because they contained insufficient or non-relevant data for this analysis. Finally, 23 eligible studies were entered into our meta-analysis (Figure 1). In three of these studies, the GA and AA genotypes were reported in overall form instead of separately, so they could be included only in the dominant-model analysis. Table 1 shows the summary of exported data from all of the included studies.

\subsection{Association Between the TNF- $\alpha-308$ G/A Polymorphism Mmodels and HCC Rrisk}

Figure 2 indicates the association of the allelic model (A vs. G) and the risk of HCC. Overall, the A allele was identified more frequently in HCC patients than in controls (13.4\% vs. $8.4 \%$, respectively). Talaat et al. (14) were the only authors to report a statistically significant difference from the overall result. In analyzing the allelic model, because of high heterogeneity (Pheterogeneity $<0.001, \mathrm{I}^{2}=85 \%$ ), a random effect model was used. Figure 2 shows that mutant allele A in TNF- $\alpha$-308 was related to increased HCC risk (P = 0.001, OR [95\% CI] = $1.77[1.26-2.50])$. For the co-dominant model (AA vs. GG), considering the significant heterogeneity among the studies (Pheterogeneity $=0.003, \mathrm{I}^{2}=55 \%$ ), a random-effect model was employed. The analysis of the codominant model $(\mathrm{P}<0.020$, OR [95\% CI] =2.14 [1.13-4.06]), shown in Figure 3, identified a possible association with 
HCC risk, but this result may be influenced by removing one study. Therefore, we deduced that this result was not reliable.

Due its significant heterogeneity (Pheterogeneity = $\left.0.006, \mathrm{I}^{2}=52 \%\right)$, a random model was used for the recessive model (Figure 4), showing a statistically significant association with the HCC risk $(\mathrm{P}<0.047$, OR $[95 \% \mathrm{CI}]=1.83[1.01-$ 3.33]). However, similar to the co-dominant model, its results were not trustworthy. After analyzing the results of selected articles for the dominant model, it was noted that there was a significant association between this model in TNF- $\alpha-308$ and the risk of HCC development $(\mathrm{P}<0.001$, OR $[95 \% \mathrm{CI}]=1.80[1.29-2.51])$. This association is clearly shown in Figure 5. Considering the high heterogeneity (Pheterogeneity $<0.001, \mathrm{I}^{2}=81 \%$ ) among the selected studies, the random model was used instead of the fixed model in the dominant model. Table 2 also summarizes the most important results for all four of the analyzed models.

\subsection{Sensitivity Analysis}

After checking the effect of omitting any given study with a sensitivity analysis, the results of the allelic and dominant models were concluded to be completely reliable, while the other two models were considered unreliable because of alterations of the overall results in the sensitivity analysis. Figure 6 shows the sensitivity analysis results for the analyzed models.

\subsection{Publication Bias}

To evaluate for any evidence of publication bias among the included studies, funnel plots for all four of the models were performed (Figure 7). The shape of these plots suggested no evidence of publication bias among the studies.

\section{Conclusions}

There are several risk factors for HCC development, including cirrhosis, HBV, HCV, toxins, drinking-water contamination, and alcohol (37). HCC most often develops as an outcome of HBV or HCV infections, which can be affected by various factors $(38,39)$. Various cytokines and cells are deeply involved in several types of diseases, such as HCC and viral hepatitis. Having a plan of their activity and functions may lead to the emergence of new therapeutic options and also better management of HBV infection $(40,41)$. For example, recently, Tavakolpour (41) used the function of cytokines and cells to introduce a new therapeutic approach for chronic HBV. Finding the association between TNF- $\alpha$ polymorphisms may also lead to the emergence of some options to better management of HCC. TNF$\alpha$ is also involved in HCC development $(42,43)$. TNF- $\alpha$ polymorphisms can regulate the expression of this cytokine, and different meta-analyses have shown an association between TNF- $\alpha$-308 G/A and the risk of HCC (44-47). However, the results for TNF-238 G/A in this context have been controversial $(44-46,48)$. Furthermore, there is limited evidence of an association between HCC and TNF-863 C/A, and no association between TNF-857 C/T or TNF-1031 T/C and the risk of HCC (19). Table 3 summarizes the results of recent metaanalyses that sought to identify links between HCC risk and different positions of TNF- $\alpha$ promoter.

The present meta-analysis investigated associations between TNF- $\alpha$-308 G/A and the risk of HCC in an allelic model and all genotype models. The results for the allelic model, reflecting 20 studies, indicated a significant association with HCC risk. This is similar to the results reported by Wang et al. (47), Hu et al. (46), and Cheng et al. (48). Due to high heterogeneity, the random model was employed for this analysis.

In addition to the A vs. G model, the AA vs. GG model was associated with HCC. However, Hu et al. (46) and Cheng et al. (48) did not report a relationship between this model and HCC risk. Thus, the present meta-analysis introduced an association between a co-dominant genotype model with HCC for the first time. However, a sensitivity analysis showed that these results should be considered unreliable. Thus, further studies are necessary to determine whether there is any significant association in this regard. In a recessive model, the $\mathrm{P}$ value was very close to 0.05 , indicating statistical significance, but this was not trustworthy, as the sensitivity analysis found no association on the recessive model between HCC risk and TNF- $\alpha$-308. Similar to our analysis, all of the published meta-analyses found no relationship on the recessive model.

For the dominant model, similar to all of the previously published meta-analyses, a significant association with HCC was found in the present study, confirming the previous results.

In all of the models, significant heterogeneity was observed. Thus, a random model was used for the analyses. In the allelic and dominant models, which were considered significantly associated with HCC in previous analyses, an association with HCC was also obtained in this study. However, this relationship may possibly exist in the co-dominant and recessive models. Differentiation of this result with previous studies was associated with the codominant model, which was not calculated in most of the other meta-analyses. Among all of the published results, Talaat's study was considerably different from the others, reporting the G allele as a risk factor for HCC. This research was carried out in Egyptian patients with chronic HCV infections. Two other studies investigated Egyptian populations, but all of them introduced the A allele as a risk factor for HCC. Our results also confirmed the A allele risk factor. 
287 Potentially Relevant Article in English language

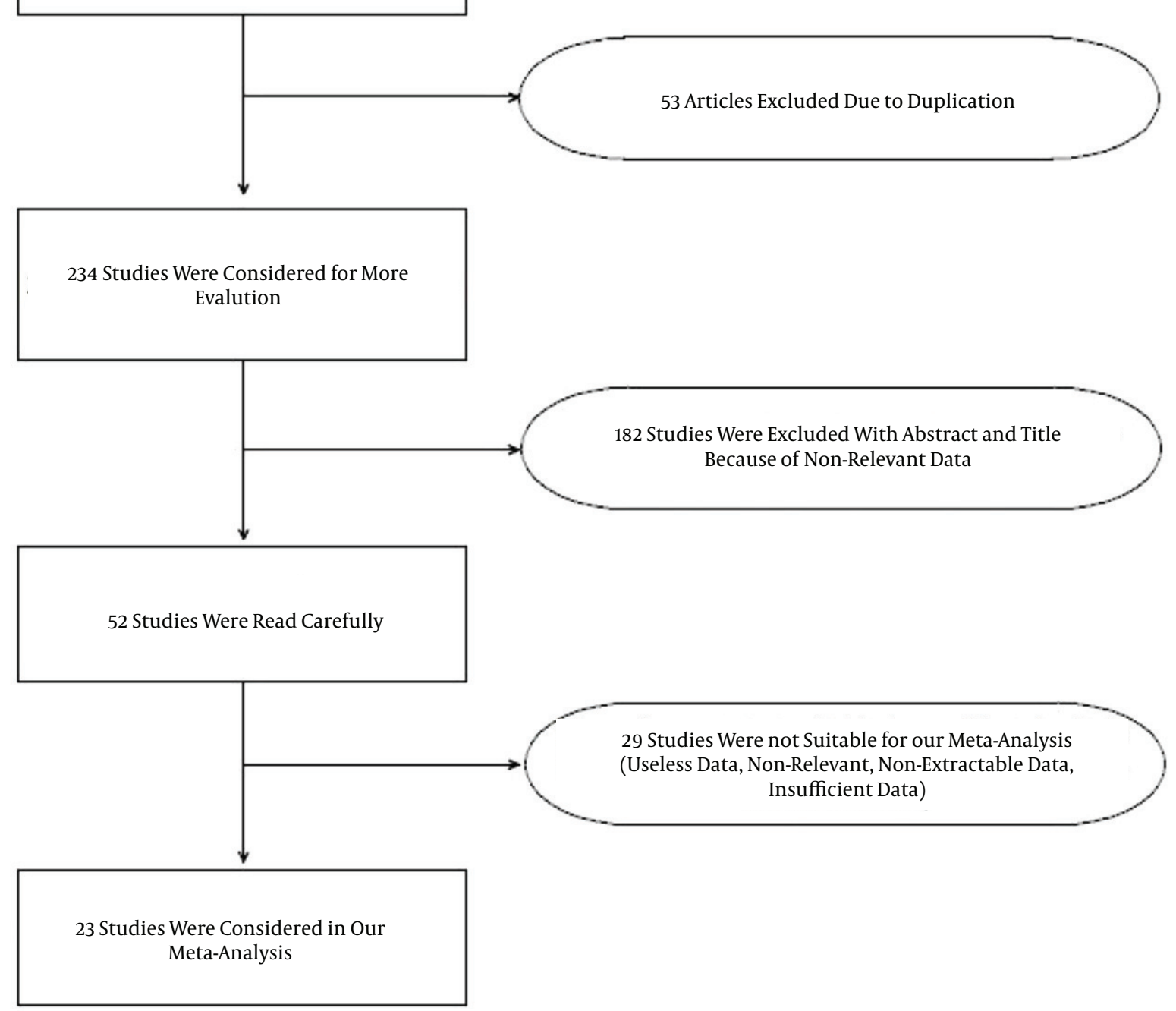

Figure 1. Flow Chart for Identifying Potential Studies for the Meta-Analysis

In other HCV cases that developed HCC, the results were not as different as they were in this study.

A sensitivity analysis, which removes one study and repeats the analysis, may reveal that the overall results depend on a certain study or not. After the sensitivity analysis in the present study, the reliability of the final results, which showed associations between the allelic and the dominant models with HCC, was confirmed. Despite an association of the co-dominant and recessive models with HCC, based on the sensitivity analysis results, this associa- tion was not trustworthy.

The present meta-analysis may suffer from certain limitations. First, only English-language studies were included, although there are studies published in other languages, especially Chinese. Another limitation is the high heterogeneity of the data, which can cause deviations from factual results. Environmental factors and primary diseases that cause HCC should also be considered, but this was impractical with the low number of included studies. In this analysis, it was assumed that all of the enrolled 
Table 1. Main Characteristics of the Studies Included in the Meta-Analysis

\begin{tabular}{|c|c|c|c|c|c|c|c|c|c|c|c|c|}
\hline \multirow[t]{2}{*}{ Study, y } & \multirow[t]{2}{*}{ Ref } & \multirow[t]{2}{*}{ Country } & \multirow[t]{2}{*}{ Study Period } & \multirow[t]{2}{*}{ Genotyping Method } & \multicolumn{4}{|c|}{ Case } & \multicolumn{4}{|c|}{ Control } \\
\hline & & & & & $\mathrm{N}$ & GG & GA & AA & $\mathbf{N}$ & GG & GA & AA \\
\hline Wang, 2003 & (15) & Japan & $2000-2001$ & Direct sequencing & 125 & 109 & 15 & 1 & 55 & 48 & 6 & 1 \\
\hline Ben-Ari, 2003 & (16) & Israel & NM & PCR-SSP & 10 & 9 & $1^{a}$ & 48 & 42 & $6^{a}$ & & \\
\hline Heneghan, 2003 & (17) & China & NM & PCR & 98 & 88 & 10 & 0 & 172 & 158 & 13 & 1 \\
\hline Но, 2004 & (18) & China & $2000-2003$ & PCR & 74 & 37 & 34 & 3 & 289 & 225 & 62 & 2 \\
\hline Niro, 2005 & (19) & Italy & $2000-2003$ & Direct sequencing & 30 & 24 & $6^{\mathrm{a}}$ & 96 & 75 & $21^{\mathrm{a}}$ & & \\
\hline Migita, 2005 & (20) & Japan & $2000-2004$ & PCR-SSP & 48 & 47 & 1 & 0 & 188 & 183 & 5 & 0 \\
\hline Chen, 2005 & (21) & China & $1997-2001$ & PCR-RFLP & 572 & 468 & 95 & 9 & 381 & 311 & 67 & 3 \\
\hline Kummee, 2007 & (22) & Thailand & NM & PCR-RFLP & 50 & 42 & 6 & 2 & 150 & 123 & 15 & 12 \\
\hline Jeng, 2007 & (23) & China & $2001-2001$ & PCR & 108 & 80 & 28 & 0 & 108 & 100 & 8 & 0 \\
\hline Sakamoto, 2008 & (24) & Japan & $2001-2004$ & PCR-RFLP & 209 & 205 & 4 & 0 & 275 & 270 & 5 & 0 \\
\hline Jeng, 2009 & (25) & China & $2003-2004$ & PCR & 200 & 149 & 50 & 1 & 200 & 188 & 12 & 0 \\
\hline Ognjanovic, 2009 & (26) & us & $1984-2001$ & TaqMan & 118 & 90 & $28^{\mathrm{a}}$ & 225 & 176 & $49^{\mathrm{a}}$ & & \\
\hline Akkiz, 2009 & (27) & Turkey & $2005 \cdot 2007$ & PCR-RFLP & 110 & 72 & 35 & 3 & 110 & 99 & 11 & 0 \\
\hline Wang, 2010 & (28) & China & NM & PCR & 230 & 197 & 30 & 3 & 158 & 143 & 15 & 0 \\
\hline Shi, 2011 & (29) & China & $2007-2009$ & PCR-RFLP & 88 & 30 & 43 & 15 & 88 & 45 & 35 & 8 \\
\hline Shi, 2012 & (30) & China & $2000-2010$ & PCR-RFLP & 73 & 51 & 20 & 2 & 116 & 84 & 30 & 2 \\
\hline Radwan, 2012 & (31) & Egypt & NM & PCR-RFLP & 128 & 82 & 42 & 4 & 160 & 136 & 24 & 0 \\
\hline Talaat, 2012 & (14) & Egypt & NM & TaqMan & 45 & 42 & 2 & 1 & 45 & 25 & 13 & 7 \\
\hline Teixeira, 2013 & (32) & Brazil & 2001-2009 & PCR & 111 & 81 & 30 & 0 & 202 & 173 & 26 & 3 \\
\hline Saxena, 2013 & (33) & India & NM & PCR-RFLP & 59 & 52 & 7 & 0 & 139 & 128 & 11 & 0 \\
\hline Feng, 2014 & (34) & China & $2010-2013$ & PCR & 753 & 611 & 98 & 44 & 760 & 733 & 25 & 2 \\
\hline Rizk, 2014 & (35) & Egypt & NM & PCR & 50 & 25 & 15 & 10 & 70 & 56 & 8 & 6 \\
\hline Sghaier, 2015 & (36) & Tunis & $2012-2013$ & PCR-RFLP & 100 & 25 & 47 & 28 & 200 & 80 & 72 & 48 \\
\hline
\end{tabular}

${ }^{\mathrm{a}} \mathrm{AA}+\mathrm{GA}$ value.

Table 2. Summarized Results of Pooled ORs in the Meta-Analysis

\begin{tabular}{|c|c|c|c|c|c|c|}
\hline Model & No. of Studies & Employed Model & OR $[95 \% \mathrm{CI}]$ & PValue & $\mathbf{P}_{\text {heterogeneity }}$ & $\mathbf{I}^{2}, \%$ \\
\hline Avs. G & 20 & Random & $1.77[1.26-2.50]$ & $<0.002$ & $<0.001$ & 85 \\
\hline AA vs. GG & 20 & Random & $2.14[1.13-4.06]$ & $<0.020$ & 0.003 & 55 \\
\hline AA vs. AG + GG & 20 & Random & $1.83[1.01-3.33]$ & $<0.047$ & 0.006 & 52 \\
\hline AA+ AG vs. GG & 23 & Random & $1.80[1.29-2.51]$ & $<0.001$ & $<0.001$ & 81 \\
\hline
\end{tabular}

Table 3. Summary of Previous Meta-Analysis Results for Different TNF- $\alpha$ Promoter Positions

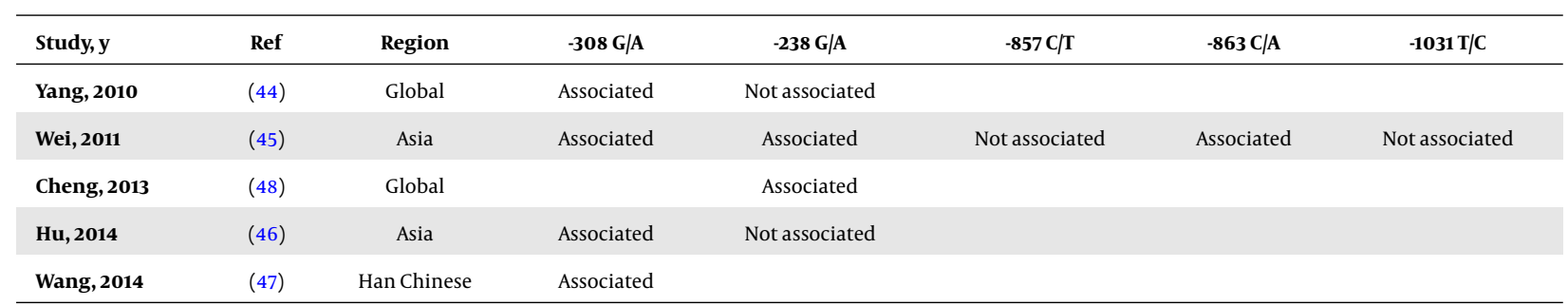

studies contained accurate data; however, this may not be true. On the other hand, there were also some advantages in this analysis that previous studies lacked. For example, this meta-analysis included 23 studies, which is the highest number among similar meta-analyses. The last update of the literature search was on July 12, 2015, which is consid- 


\begin{tabular}{|c|c|c|c|c|c|c|}
\hline \multirow[t]{2}{*}{ Study Name } & \multicolumn{3}{|c|}{ Statistics For Each Study } & \multirow[b]{2}{*}{ p-Value } & \multirow[t]{2}{*}{ MH odds Ratio and 95\% CI } & \multirow[b]{2}{*}{$\begin{array}{l}\text { Relative } \\
\text { Weight }\end{array}$} \\
\hline & $\begin{array}{l}\text { MH odds } \\
\text { Ratio }\end{array}$ & $\begin{array}{l}\text { Lower } \\
\text { Limit }\end{array}$ & $\begin{array}{l}\text { Upper } \\
\text { Limit }\end{array}$ & & & \\
\hline Wang (2003) & 0.930 & 0.389 & 2.225 & 0.87091 & & 4.57 \\
\hline Heneghan (2003) & 1.179 & 0.519 & 2.678 & 0.69361 & & 4.73 \\
\hline Ho (2004) & 2.873 & 1.843 & 4.480 & 0.00000 & & 5.84 \\
\hline Migita (2005) & 0.781 & 0.090 & 6.765 & 0.82249 & & 1.83 \\
\hline Chen (2005) & 1.034 & 0.759 & 1.410 & 0.83020 & & 6.14 \\
\hline Kummee (2007) & 0.744 & 0.357 & 1.551 & 0.42944 & & 4.99 \\
\hline Jeng (2007) & 3.872 & 1.722 & 8.706 & 0.00105 & & 4.76 \\
\hline Sakamoto (2008) & 1.053 & 0.281 & 3.946 & 0.93877 & & 3.31 \\
\hline Jeng (2009) & 4.831 & 2.537 & 9.201 & 0.00000 & & 5.27 \\
\hline Akkiz (2009) & 4.352 & 2.172 & 8.718 & 0.00003 & & 5.12 \\
\hline Wang (2010) & 1.704 & 0.916 & 3.168 & 0.09219 & & 5.34 \\
\hline Shi (2011) & 1.737 & 1.116 & 2.704 & 0.01449 & & 5.84 \\
\hline Shi (2012) & 1.146 & 0.648 & 2.024 & 0.63969 & & 5.49 \\
\hline Radwan (2012) & 2.994 & 1.783 & 5.026 & 0.00003 & & 5.64 \\
\hline Talaat ( 2012) & 0.109 & 0.036 & 0.326 & 0.00008 & & 3.90 \\
\hline Teixeira (2013) & 1.816 & 1.072 & 3.079 & 0.02662 & & 5.61 \\
\hline Saxena (2013) & 1.531 & 0.578 & 4.051 & 0.39119 & & 4.26 \\
\hline Feng (2014) & 7.245 & 4.865 & 10.789 & 0.00000 & & 5.95 \\
\hline Rizk (2014) & 3.231 & 1.726 & 6.047 & 0.00025 & & 5.32 \\
\hline \multirow[t]{3}{*}{ Sghaier (2015) } & 1.466 & 1.043 & 2.062 & 0.02782 & & 6.08 \\
\hline & 1.772 & 1.255 & 2.500 & 0.00114 & & \\
\hline & & & & & 0.1 & 100 \\
\hline
\end{tabular}

Figure 2. ORs and CIs of HCC risk Associated With TNF- $\alpha$-308 G/A for the A Allele in Comparison to the G Allele (Allelic Model)

\begin{tabular}{lcccc} 
Study Name & \multicolumn{4}{c}{ Statistics for Each Study } \\
& $\begin{array}{c}\text { MH odds } \\
\text { Ratio }\end{array}$ & $\begin{array}{c}\text { Lower } \\
\text { Limit }\end{array}$ & $\begin{array}{c}\text { Upper } \\
\text { Limit }\end{array}$ & P-Value \\
Wang(2003) & 0.440 & 0.027 & 7.188 & 0.56487 \\
Heneghan(2003) & 0.597 & 0.024 & 14.810 & 0.75287 \\
Ho (2004) & 9.122 & 1.474 & 56.448 & 0.01745 \\
Migita (2005) & 0.774 & 0.088 & 6.787 & 0.81705 \\
Chen(2005) & 1.994 & 0.536 & 7.422 & 0.30361 \\
Kumme(2007) & 0.488 & 0.105 & 2.271 & 0.36051 \\
Jeng(2009) & 3.783 & 0.153 & 93.523 & 0.41629 \\
Akkiz(2009) & 9.607 & 0.489 & 188.875 & 0.13655 \\
Wang(2010) & 5.086 & 0.261 & 99.234 & 0.28327 \\
Shi (2011) & 2.813 & 1.061 & 7.453 & 0.03755 \\
Shi (2011) & 1.647 & 0.225 & 12.056 & 0.62321 \\
Radwan(2012) & 14.891 & 0.792 & 280.129 & 0.07126 \\
Talaat(2012) & 0.085 & 0.010 & 0.732 & 0.02485 \\
Teixeira(2013) & 0.304 & 0.016 & 5.957 & 0.43290 \\
Feng(2014) & 26.393 & 6.372 & 109.312 & 0.00001 \\
Rizk(2014) & 3.733 & 1.222 & 11.403 & 0.02076 \\
Sghaier(2015) & 1.867 & 0.977 & 3.566 & 0.05875 \\
& 2.144 & 1.133 & 4.057 & 0.01909
\end{tabular}

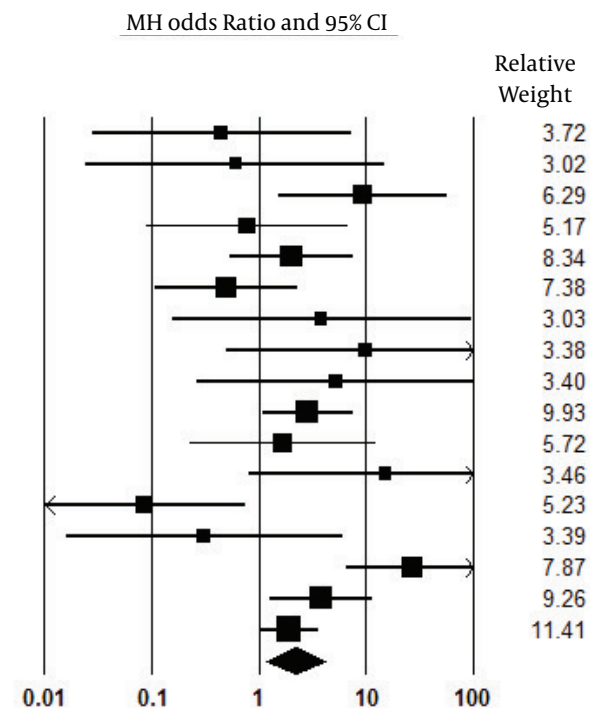

Figure 3. ORs and CIs of HCC risk Associated With TNF- $\alpha$-308 G/A for the AA Genotype Compared to the GG Gonotype (co-Dominant Effect) 
Study Name

$\begin{array}{lccc} & \begin{array}{c}\text { MH odds } \\ \text { Ratio }\end{array} & \begin{array}{c}\text { Lower } \\ \text { Limit }\end{array} & \begin{array}{c}\text { Upper } \\ \text { Limit }\end{array} \\ \text { Wang (2003) } & 0.435 & 0.027 & 7.091 \\ \text { Henefhan(2003) } & 0.580 & 0.023 & 14.384 \\ \text { Ho (2004) } & 6.063 & 0.994 & 36.974 \\ \text { Migita (2005) } & 0.779 & 0.089 & 6.826 \\ \text { Chen(2005) } & 2.014 & 0.542 & 7.488 \\ \text { Kummee (2007) } & 0.479 & 0.103 & 2.219 \\ \text { Jeng (2009) } & 3.015 & 0.122 & 74.457 \\ \text { Akkiz (2009) } & 7.195 & 0.367 & 140.962 \\ \text { Wang(2010) } & 4.877 & 0.250 & 95.072 \\ \text { Shi (2011) } & 2.055 & 0.823 & 5.130 \\ \text { Shi (2012) } & 1.606 & 0.221 & 11.655 \\ \text { Radwan(2012) } & 11.602 & 0.619 & 217.525 \\ \text { Talaat (2012) } & 0.123 & 0.015 & 1.048 \\ \text { Teixeria (2013) } & 0.256 & 0.013 & 4.993 \\ \text { Feng (2014) } & 23.520 & 5.681 & 97.380 \\ \text { Rizk(2014) } & 2.667 & 0.900 & 7.904 \\ \text { Sghaier(2015) } & 1.231 & 0.715 & 2.122 \\ & 1.833 & 1.010 & 3.327\end{array}$

Statistics for Each Study

P-Value
0.55926
0.73975
0.05073
0.82135
0.29595
0.34676
0.49996
0.19357
0.29574
0.12285
0.63964
0.10120
0.05528
0.36837
0.00001
0.07683
0.45308
0.04633

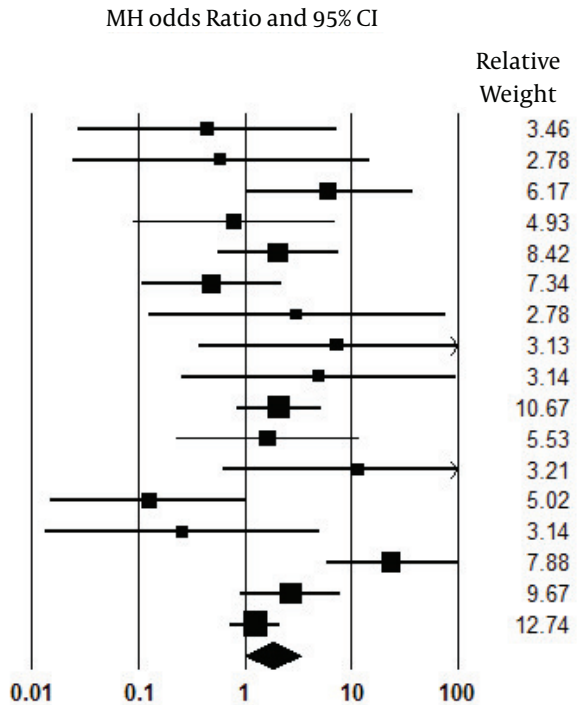

Figure 4. ORs and CIs of HCC risk Associated With TNF-A-308 G/A for the AA Genotype Compared to the AG + GG Genotype (Recessive Effect)

\begin{tabular}{|c|c|c|c|c|}
\hline \multirow[t]{2}{*}{ Study Name } & \multicolumn{4}{|c|}{ Statistics for Each Study } \\
\hline & $\begin{array}{l}\text { MH odds } \\
\text { Ratio }\end{array}$ & $\begin{array}{l}\text { Lower } \\
\text { Limit }\end{array}$ & $\begin{array}{l}\text { Upper } \\
\text { Limit }\end{array}$ & P-Value \\
\hline Wang (2003) & 1.007 & 0.389 & 2.605 & 0.98926 \\
\hline Ben-Ari (2003) & 0.778 & 0.083 & 7.277 & 0.82565 \\
\hline Heneghan (2003) & 1.282 & 0.547 & 3.008 & 0.56727 \\
\hline Нo (2004) & 3.516 & 2.062 & 5.994 & 0.00000 \\
\hline Niro (2005) & 0.893 & 0.323 & 2.469 & 0.82713 \\
\hline Migita (2005) & 0.779 & 0.089 & 6.826 & 0.8213 \\
\hline Chen (2005) & 0.987 & 0.706 & 1.380 & 0.9404 \\
\hline Kummee (2007) & 0.868 & 0.366 & 2.057 & 0.7473 \\
\hline Jeng (2007) & 4.375 & 1.891 & 10.123 & 0.0005 \\
\hline Sakamoto (2008) & 1.054 & 0.279 & 3.973 & 0.9384 \\
\hline Jeng (2009) & 5.362 & 2.759 & 10.423 & 0.0000 \\
\hline Ognjanovic (2009) & 1.117 & 0.658 & 1.897 & 0.6808 \\
\hline Akkiz (2009) & 4.750 & 2.274 & 9.921 & 0.0000 \\
\hline Wang (2010) & 1.597 & 0.836 & 3.050 & 0.1563 \\
\hline Shi (2011) & 2.023 & 1.102 & 3.714 & 0.0229 \\
\hline Shi (2012) & 1.132 & 0.594 & 2.158 & 0.7055 \\
\hline Radwan (2012) & 3.179 & 1.808 & 5.590 & 0.0000 \\
\hline Talaat (2012) & 0.089 & 0.024 & 0.331 & 0.0003 \\
\hline Teixeira (2013) & 2.209 & 1.244 & 3.925 & 0.0068 \\
\hline Saxena (2013) & 1.566 & 0.576 & 4.262 & 0.3795 \\
\hline Feng (2014) & 6.309 & 4.124 & 9.653 & 0.0000 \\
\hline $\operatorname{Rizk}(2014)$ & 4.000 & 1.786 & 8.959 & 0.0007 \\
\hline Sghaier (2015) & 2.000 & 1.173 & 3.411 & 0.0109 \\
\hline & 1.799 & 1.288 & 2.512 & 0.0005 \\
\hline
\end{tabular}

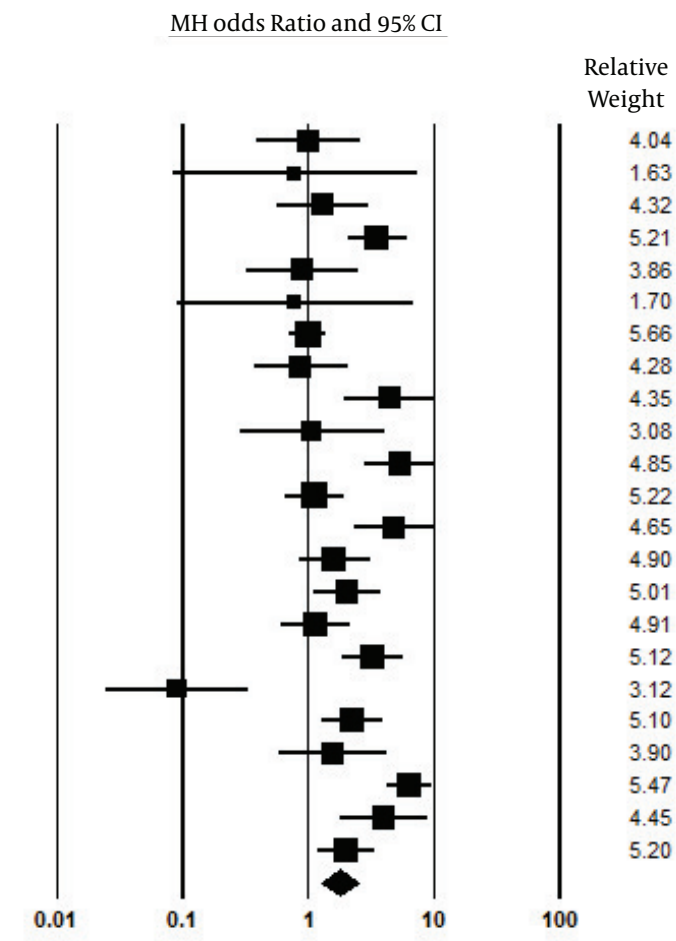

Figure 5. ORs and CIs of HCC risk Associated With TNF- $\alpha$-308 G/A for the AA + AG Genotype Compared to the GG Genotype (Dominant Effect) 


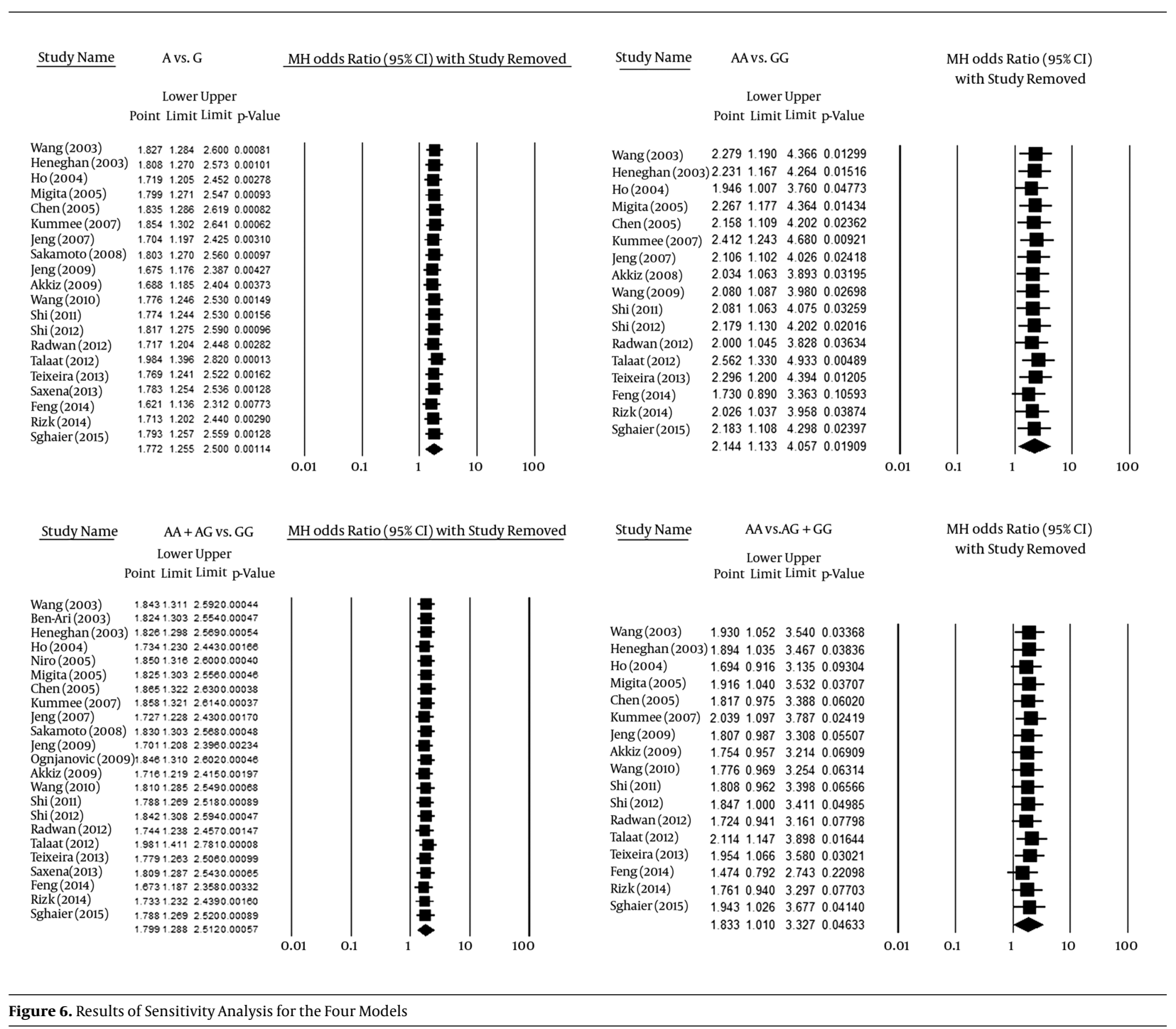


A

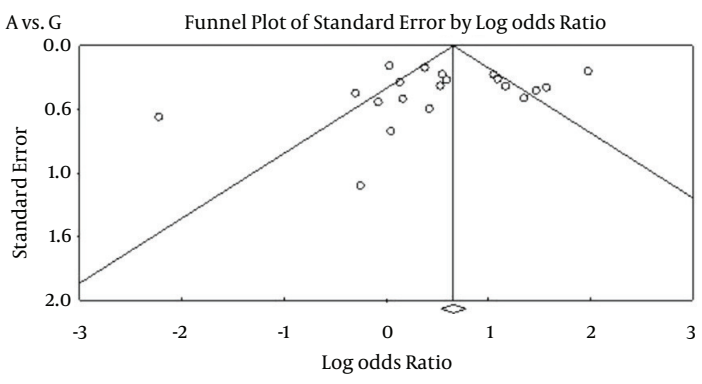

C

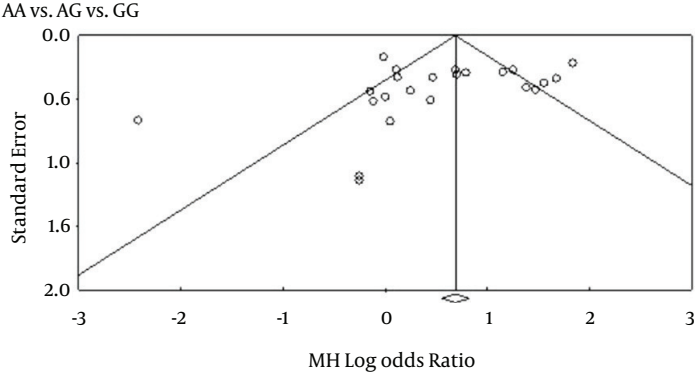

B

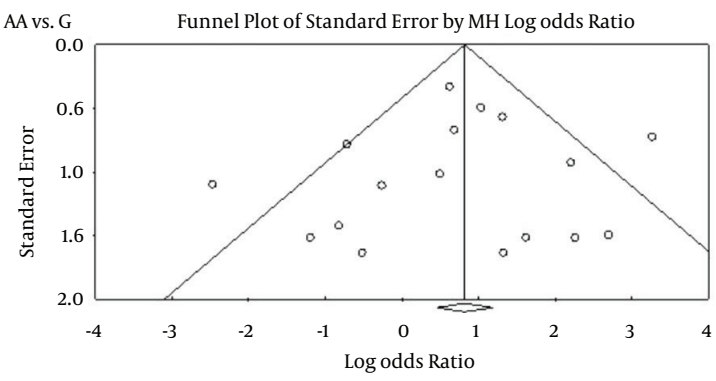

D

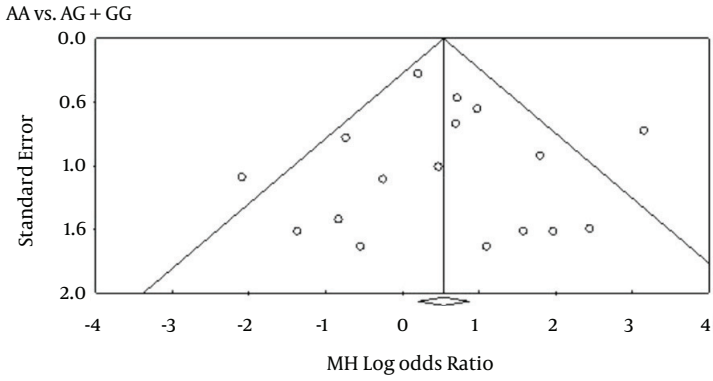

Figure 7. Funnel Plot Analysis to Examine Publication Bias for all Analyzed Models

erably more recent than the last meta-analysis. To obtain more valid and reliable results, future studies are needed.

\section{Footnotes}

Authors' Contribution: Study concept and design: Soheil Tavakolpour and Shahnaz Sali; acquisition of data: Soheil Tavakolpour; analysis and interpretation of data: Soheil Tavakolpour and Shahnaz Sali; drafting of the manuscript: Soheil Tavakolpour; critical revision of the manuscript for important intellectual content: Soheil Tavakolpour and Shahnaz Sali; statistical analysis: Soheil Tavakolpour and Shahnaz Sali; administrative, technical, and material support: Soheil Tavakolpour and Shahnaz Sali; study supervision: Soheil Tavakolpour and Shahnaz Sali.

Financial Disclosure: This study did not receive financial support.

\section{References}

1. Ferlay J, Shin HR, Bray F, Forman D, Mathers C, Parkin DM. Estimates of worldwide burden of cancer in 2008: GLOBOCAN 2008. Int J Cancer. 2010;127(12):2893-917. doi:10.1002/ijc.25516. [PubMed: 21351269].

2. Perz JF, Armstrong GL, Farrington LA, Hutin YJ, Bell BP. The contributions of hepatitis B virus and hepatitis $C$ virus infections to cirrhosis and primary liver cancer worldwide.J Hepatol. 2006;45(4):529-38. doi:10.1016/j.jhep.2006.05.013. [PubMed: 16879891].
3. Jang MK, Su Kim H, Chung YH. Clinical aspects of tumor necrosis factor- $\alpha$ signaling in hepatocellular carcinoma. Curr Pharm Des. 2014;20(17):2799-808. doi: 10.2174/13816128113199990587.

4. Wang X, Lin Y. Tumor necrosis factor and cancer, buddies or foes?. Acta Pharmacol Sin. 2008;29(11):1275-88. doi: 10.1111/j.17457254.2008.00889.x. [PubMed: 18954521].

5. Balkwill F. TNF-alpha in promotion and progression of cancer. Cancer Metastasis Rev. 2006;25(3):409-16. doi:10.1007/s10555-006-9005-3. [PubMed: 16951987].

6. Huang YS, Hwang SJ, Chan CY, Wu JC, Chao Y, Chang FY, et al. Serum levels of cytokines in hepatitis C-related liver disease: a longitudinal study. Zhonghua Yi Xue Za Zhi (Taipei). 1999;62(6):327-33. [PubMed: 10389289].

7. Nakazaki H. Preoperative and postoperative cytokines in patients with cancer. Cancer. 1992;70(3):709-13. doi: 10.1002/10970142(19920801)70:3<709::AID-CNCR2820700328>3.0.CO;2-O.

8. Bortolami M, Venturi C, Giacomelli L, Scalerta R, Bacchetti S, Marino F, et al. Cytokine, infiltrating macrophage and T cell-mediated response to development of primary and secondary human liver cancer. Dig Liver Dis. 2002;34(11):794-801. doi:10.1016/S1590-8658(02)80073-1.

9. Zekri AR, Ashour MS, Hassan A, Alam El-Din HM, El-Shehaby AM, AbuShady MA. Cytokine profile in Egyptian hepatitis $C$ virus genotype4 in relation to liver disease progression. World J Gastroenterol. 2005;11(42):6624-30. [PubMed:16425355].

10. Tavakolpour S, Alavian SM, Sali S. Hepatitis B Reactivation During Immunosuppressive Therapy or Cancer Chemotherapy, Management, and Prevention: A Comprehensive Review. Hepat Mon. ;Inpress(Inpress):e35810. doi: 10.5812/hepatmon.35810.

11. Wilson AG, di Giovine FS, Blakemore AI, Duff GW. Single base polymorphism in the human tumour necrosis factor alpha (TNF alpha) gene detectable by NcoI restriction of PCR product. Hum Mol Genet. 1992;1(5):353. [PubMed: 1363876]. 
12. Abraham LJ, Kroeger KM. Impact of the -308 TNF promoter polymorphism on the transcriptional regulation of the TNF gene: relevance to disease. J Leukoc Biol. 1999;66(4):562-6. [PubMed: 10534109].

13. Wilson AG, Symons JA, McDowell TL, McDevitt HO, Duff GW. Effects of a polymorphism in the human tumor necrosis factor $\alpha$ promoter on transcriptional activation. Proc Natl Acad Sci. 1997;94(7):3195-9. doi: 10.1073/pnas.94.7.3195.

14. Talaat RM, Esmail AA, Elwakil R, Gurgis AA, Nasr MI. Tumor necrosis factor-alpha-308G/A polymorphism and risk of hepatocellular carcinoma in hepatitis C virus-infected patients. Chin J Cancer. 2012;31(1):29-35.

15. Wang Y, Kato N, Hoshida Y, Yoshida H, Taniguchi H, Goto T, et al. Interleukin-1beta gene polymorphisms associated with hepatocellular carcinoma in hepatitis C virus infection. Hepatology. 2003;37(1):6571. doi: 10.1053/jhep.2003.50017. [PubMed: 12500190].

16. Ben-Ari Z, Mor E, Papo O, Kfir B, Sulkes J, Tambur AR, et al. Cytokine gene polymorphisms in patients infected with hepatitis B virus. Am J Gastroenterol. 2003;98(1):144-50. doi: 10.1111/j.1572-0241.2003.07179.x. [PubMed: 12526950].

17. Heneghan MA, Johnson PJ, Clare M, Ho S, Harrison PM, Donaldson PT. Frequency and nature of cytokine gene polymorphisms in hepatocellular carcinoma in Hong Kong Chinese. Int J Gastrointest Cancer. 2003;34(1):19-26. doi:10.1385/IJGC:34:1:19.

18. Ho SY, Wang YJ, Chen HL, Chen CH, Chang CJ, Wang PJ, et al. Increased risk of developing hepatocellular carcinoma associated with carriage of the TNF2 allele of the -308 tumor necrosis factoralpha promoter gene. Cancer Causes Control. 2004;15(7):657-63. doi: 10.1023/B:CACO.0000036173.99930.75. [PubMed: 15280623].

19. Niro GA, Fontana R, Gioffreda D, Valvano MR, Lacobellis A, Facciorusso $\mathrm{D}$, et al. Tumor necrosis factor gene polymorphisms and clearance or progression of hepatitis B virus infection. Liver Int. 2005;25(6):1175-81. doi: 10.1111/j.1478-3231.2005.01166.x. [PubMed: 16343069].

20. Migita K, Miyazoe S, Maeda Y, Daikoku M, Abiru S, Ueki T, et al. Cytokine gene polymorphisms in Japanese patients with hepatitis B virus infection-association between TGF-beta1 polymorphisms and hepatocellular carcinoma. J Hepatol. 2005;42(4):505-10. doi: 10.1016/j.jhep.2004.11.026. [PubMed: 15763337].

21. Chen CC, Yang SY, Liu CJ, Lin CL, Liaw YF, Lin SM, et al. Association of cytokine and DNA repair gene polymorphisms with hepatitis Brelated hepatocellular carcinoma. Int J Epidemiol. 2005;34(6):1310-8. doi: 10.1093/ije/dyi191. [PubMed: 16172101].

22. Kummee $P$, Tangkijvanich P, Poovorawan Y, Hirankarn N. Association of HLA-DRB ${ }^{*} 13$ and TNF-alpha gene polymorphisms with clearance of chronic hepatitis B infection and risk of hepatocellular carcinoma in Thai population. J Viral Hepat. 2007;14(12):841-8. doi: 10.1111/j.13652893.2007.00880.x. [PubMed: 18070287].

23. Jeng JS, Tsai JF, Chuang LY, Ho MS, Lin ZY, Hsieh MY, et al. Tumor necrosis factor- $\alpha 308.2$ polymorphism is associated with advanced hepatic fibrosis and higher risk for hepatocellular carcinoma. Neoplasia. 2007;9(11):987-92. doi:10.1593/neo.07781.

24. Sakamoto T, Higaki Y, Hara M, Ichiba M, Horita M, Mizuta T, et al. Interaction between interleukin-1beta -31T/C gene polymorphism and drinking and smoking habits on the risk of hepatocellular carcinoma among Japanese. Cancer Lett. 2008;271(1):98-104. doi: 10.1016/j.canlet.2008.05.036. [PubMed:18603357].

25. Jeng JE, Tsai HR, Chuang LY, Tsai JF, Lin ZY, Hsieh MY, et al. Independent and additive interactive effects among tumor necrosis factor-alpha polymorphisms, substance use habits, and chronic hepatitis $\mathrm{B}$ and hepatitis $\mathrm{C}$ virus infection on risk for hepatocellular carcinoma. Medicine (Baltimore). 2009;88(6):349-57. doi: 10.1097/MD.ob013e3181c10477. [PubMed: 19910749].

26. Ognjanovic S, Yuan JM, Chaptman AK, Fan Y, Yu MC. Genetic polymorphisms in the cytokine genes and risk of hepatocellular carcinoma in low-risk non-Asians of USA. Carcinogenesis. 2009;30(5):758-62. doi: 10.1093/carcin/bgn286. [PubMed: 19126646].

27. Akkiz H, Bayram S, Bekar A, Ozdil B, Akgollu E, Sumbul AT, et al. G-308A TNF-alpha polymorphism is associated with an increased risk of hepatocellular carcinoma in the Turkish population: case-control study. Cancer Epidemiol. 2009;33(3-4):261-4. doi 10.1016/j.canep.2009.06.001. [PubMed: 19683483].

28. Wang B, Wang J, Zheng Y, Zhou S, Zheng J, Wang F, et al. A study of TNFalpha-238 and -308 polymorphisms with different outcomes of persistent hepatitis B virus infection in China. Pathology. 2010;42(7):674-80. doi: 10.3109/00313025.2010.523696. [PubMed: 21080879].

29. Shi Z, Du C. Tumor necrosis factor alpha $308 \mathrm{G} / \mathrm{A}$ polymorphism and hepatocellular carcinoma risk in a Chinese population. Genet Test Mol Biomarkers. 2011;15(7-8):569-72. doi: 10.1089/gtmb.2011.0008. [PubMed: 21401328].

30. Shi HZ, Ren P, Lu QJ, Niedrgethmnn M, Wu GY. Association between EGF, TGF-beta1 and TNF-alpha gene polymorphisms and hepatocellular carcinoma. Asian Pac J Cancer Prev. 2012;13(12):6217-20. [PubMed: 23464434].

31. Radwan MI, Pasha HF, Mohamed RH, Hussien HI, El-Khshab MN. Influence of transforming growth factor-beta1 and tumor necrosis factoralpha genes polymorphisms on the development of cirrhosis and hepatocellular carcinoma in chronic hepatitis $\mathrm{C}$ patients. Cytokine. 2012;60(1):271-6. doi:10.1016/j.cyto.2012.05.010. [PubMed: 22682513].

32. Teixeira AC, Mendes CJ, Marano LA, Deghaide NH, Secaf M, Elias JJ, et al Alleles and genotypes of polymorphisms of IL-18, TNF-alpha and IFNgamma are associated with a higher risk and severity of hepatocellular carcinoma (HCC) in Brazil. Hum Immunol. 2013;74(8):1024-9. doi: 10.1016/j.humimm.2013.04.029. [PubMed: 23632060].

33. Saxena R, Chawla YK, Verma I, Kaur J. IFN-gamma (+874) and not TNF-alpha (-308) is associated with HBV-HCC risk in India. Mol Cell Biochem. 2014;385(1-2):297-307. doi: 10.1007/s11010-013-1838-9. [PubMed: 24101445].

34. Feng H, Kuai JH, Zhang MY, Wang GC, Shi YJ, Zhang JY. Tumor necrosis factor-alpha gene -308G > A polymorphism alters the risk of hepatocellular carcinoma in a Han Chinese population. Diagn Pathol. 2014;9:199. doi: 10.1186/s13000-014-0199-3. [PubMed: 25420786].

35. Rizk EB, Amr ER, Mohamed Abd EM, Ghada A. Interleukin-1Beta and Tumor Necrosis Factor-Alpha Genes Polymorphism and Hepatocellular Carcinoma in Patients with Hepatitis C Virus in Egyptian Population. Indian J Appl Res. 2014;4(2).

36. Sghaier I, Zidi S, Mouelhi L, Dabbech R, Ghazouani E, Brochot E, et al. The relationship between TNF alpha gene polymorphisms (238/-308), TNF RII VNTR (p75) and outcomes of hepatitis B virus infection in Tunisian population. Gene. 2015;568(2):140-5. doi: 10.1016/j.gene.2015.05.029. [PubMed: 25982858].

37. Gao J, Xie L, Yang WS, Zhang W, Gao S, Wang J, et al. Risk factors of hepatocellular carcinoma-current status and perspectives. Asian Pac JCancer Prev. 2012;13(3):743-52. [PubMed: 22631642].

38. Sali S, Alavian SM, Foster GR, Keyvani H, Mehrnoosh L, Mohammadi N. Influencing Factors on the Outcome and Prognosis of Patients With HBV Infction: Seven Years Follow-up. Hepat Mon. 2013;13(7) doi: 10.5812/hepatmon.8743.

39. Civan J, Hann HW. Hepatitis C virus mediated hepatocellular carcinoma: a focused review for a time of changing therapeutic options. $N$ Am J Med Sci. 2014;7(1):37. doi: 10.7156/najms.2014.0701008.

40. Tavakolpour $S$. The new insight into management of hepatitis B virus patients with flare. Immunology letters. 2016:173-77.

41. Tavakolpour S. Inhibition of regulatory cells as a possible cure of chronically hepatitis B virus infected patients. Immunology letters. 2016;171:70-1.

42. Seitz HK, Stickel F. Molecular mechanisms of alcohol-mediated carcinogenesis. Nat Rev Cancer. 2007;7(8):599-612. doi: 10.1038/nrc2191. [PubMed: 17646865].

43. Wullaert A, van Loo G, Heyninck K, Beyaert R. Hepatic tumor necrosis factor signaling and nuclear factor-kappaB: effects on liver homeostasis and beyond. Endocr Rev. 2007;28(4):365-86. doi: 10.1210/er.20060031. [PubMed: 17431229]. 
44. Yang Y, Luo C, Feng R, Bi S. The TNF-alpha, IL-1B and IL-10 polymorphisms and risk for hepatocellular carcinoma: a meta-analysis. J Cancer Res Clin Oncol. 2011;137(6):947-52. doi: 10.1007/s00432-010-0959-8. [PubMed: 21107607].

45. Wei Y, Liu F, Li B, Chen X, Ma Y, Yan L, et al. Polymorphisms of tumor necrosis factor-alpha and hepatocellular carcinoma risk: a HuGE systematic review and meta-analysis. Dig Dis Sci. 2011;56(8):2227-36. doi: 10.1007/s10620-011-1617-y. [PubMed: 21336601].

46. Hu Q, Lou GG, Liu YC, Qian L, Lv BD. The Tumor Necrosis Factoralpha-308 and -238 Polymorphisms and Risk of Hepatocellular Carcinoma for Asian Populations: A Meta-Analysis. Curr Ther Res Clin
Exp. 2014;76:70-5. doi: 10.1016/j.curtheres.2014.04.001. [PubMed: 25352937].

47. Wang F, Chen S, Xu R. WITHDRAWN: Association of TNF- $\alpha-308 \mathrm{G}>\mathrm{A}$ polymorphisms with hepatocellular carcinoma in Han Chinese population: A systematic review and meta-analysis. Clin Res Hepatol Gastroenterol. 2014 doi: 10.1016/j.clinre.2014.10.004.

48. Cheng K, Zhao YJ, Liu L, Wan JJ. Tumor necrosis factor-alpha $238 \mathrm{G} / \mathrm{A}$ polymorphism and risk of hepatocellular carcinoma: evidence from a meta-analysis. Asian Pac J Cancer Prev. 2013;14(5):3275-9. [PubMed: 23803115]. 